\title{
THE HIGHER EDUCATION FINANCING BASED ON ISLAMIC SHARIAH: AN UNCONVENTIONAL APPROACH OF STUDENT LOAN
}

\author{
Nor Effuandy Pfordten \\ Department of Accounting, Finance and Muamalat \\ Faculty of Business and Accountancy \\ University Selangor, Shah Alam, Malaysia \\ E-mail: pfordten@unisel.edu.my \\ Md. Jafor Ali \\ Faculty of Business Administration \\ Islamic University Kusthia, Bangladesh \\ E-mail: jaforkb@gmail.com \\ Norhaila Bt. Sabli \\ Centre of Professional and Business Development \\ Faculty of Business and Accountancy \\ University Selangor, Shah Alam, Malaysia \\ E-mail: norhayla@unisel.edu.my \\ Md. Kamal Uddin \\ Faculty of Business Administration \\ Islamic University Kusthia, Bangladesh \\ E-mail: uddinkamal1983.ku@gmail.com \\ Abul Bashar Bhuiyan \\ Department of Accounting, Finance and Muamalat \\ Faculty of Business and Accountancy \\ University Selangor, Malaysia \\ E-mail: bashariuk@gmail.com
}

\begin{abstract}
Quality Higher Education transforms human life into meaningful human resources. Moreover, it brings qualitative changes in humankind and socioeconomic development with the help of extended knowledge and higher skills. But, most of the traditional student loan mechanisms are based on interest (riba) therefore, many devout Muslims are struggling with traditional student financing, as interest (riba) is impermissible in Islamic shariah. This study aims to analyze student financing concepts based on shariah perspective and to evaluate the shariah issues that are associated to its application. The present qualitative study adopts mostly relied primary and secondary sources of Islamic shariah such as Quran, Hadith, Islamic Jurisprudence, and Islamic scholars' views. The deliberations evolve at reviewing on the shariah concept of Qard-al-hassan, Qard-bil-ujrah, waqf (Islamic trust bank), and takaful. Finally, the present study highlights that the higher education
\end{abstract}


financing based on the shariah concept could also be generalized into education financing that would be interest(riba) free and acceptable to the Muslim community at large.

Keywords: Education Financing, Shariah Based Financing, Qard Al Hassan, Qard Bil Ujrah, Waqf, and Takaful.

\section{INTRODUCTION}

Investment in quality higher education is socially and economically productive investment (Blom \& Canton, 2004; Psacharopoulos, 1986) as it promotes acquiring extended knowledge, skills, and intelligence (Chaiwut, Rueangsirarak, \& Chaisricharoen, 2018). More importantly, the quality higher education is improving knowledge level for discovering, generating, and apprehending, capturing, sharing, and motivating students for promoting their personal and collective development (Natek \& Lesjak, 2011; Simon, Małgorzata, \& Beatriz, 2007). Since the education is opening the horizon of individually life-changing opportunities and socially cost-effective returns, so the enrollments of higher education level students are increasing significantly throughout the world and so as to the costs do. Thus, the higher education loan is deliberated as an important student financing mechanism due to budgetary austerity and dwindling natural resources (Baum, 2016; Psacharopoulos, 1986; Ziderman, 2002). However, mounting costs and demands coupled with dwindling national resources lead to cost-sharing among government, students, parents, and households and finally developed a dominant mechanism of subsidized higher education loan over the seventy countries around the world (Johnstone \& Shroff-Mehta, 2003; Salmi, 2003). Besides the cost sharing, initiation of education loan involves other influences such as enhancing accessibility of needy students can collect the funds to pay for education (Ziderman, 2013); human capital development (Avery \& Turner, 2012; Becker, 1975; Li, 2013; Mueller \& Rockerbie, 2004); financial sustainability of higher education institutions (Mussa, 2015; Ziderman, 2013).

In the conventional student loan processes, Eligible applicants can apply up to a certain amount of money for their tuition and maintenance costs. Successful applicants must gradually repay the loan along with predetermined interest after they graduated and secured jobs with the income above a particular threshold. The traditional student loan mechanism is mostly interest based. But interest (riba) is completely impermissible in Islamic shariah. Thus, potential, underprivileged, and devoted Muslim students are unable to take the traditional student financing due to interest (riba) issue. As a result underprivileged Muslim youths cannot attend in the quality higher education so they are retreating from the mainstream of the society. Moreover, higher interest rate on the conventional student financing is creating enormous delinquency problems. In this case, apart from the conventional student loan, the shariah compliant student financing can resolve the issues and communal interest in line with the guidance of Quran, Hadith (sunnah), al fiqh or Islamic jurisprudence. The present endeavor aims to conceptualize shariah based financing concept and its application of Qard al Hassan (benevolent loan), Qard bil ujrah (Fee or charges of services), Waqf (Islamic trust Bank), and takaful (cooperative or solidarity based mutual guarantee) in higher education financing.

\section{LITERATURE REVIEW}

In the philosophy of Islamic economics and finance the generous role of qard al hassan, qard bil ujrah, waqf (Islamic trust bank), and takaful initiatives are invariably and empathically emphasized. Apart from the interest based student loan which is oppressive and unjust to the humankind, the interst free Islamic student financing modes such as qard al hassan, qard bil ujrah, waqf (Islamic trust bank), and takaful which help bringing socioeconomic justice and overall welfare of the society. The Islamic modes of student financing are well supported by Quran, Hadith (sunnah), Ijma 
(consensus), Qiyan (analogy), and various Islamic scholars, logicians, and philosophers. Aslam, Haneef et al., 2015 revealed that qard al hassan based financial products by any Islamic financial institutions helps to upgrade the knowledge and skills of the recipients. Moreover, Muneer, F., \& Khan, F., 2019 argued that Qard al hassan can be used as an instrument to develop human resources to bring the underprivileged Muslim youths to the mainstream of the society. The Ujrah based student financing can be considered as the simplest form out of other structured presently used in Islamic financial institutions. The financial institutions charge the recipients after completing studies or upon engagement in job or works, a fee to the client for service provided like monthly and annual charge, fixed management charge as their profits (Jamaan et al., 2014).

Another sharia based concept of Waqf or endowment plays an important role in bringing out the equality and human development for the nation. Aziz M. R. A et al., 2014 stated that Islamic waqf bank benefits the students and also their parents, financing student education in term of fees and cost of living. (Aziz et al., 2014; Yalawae et al., 2003) stated that the investment of waqf fund in human capital is considered as one of the best utilization of fund. Wahyu Jatmiko, 2018 narrated that introduction of waqf fund into higher education financing can potentially increase future national productivity. Islahi, 1992 stated that the internationalization of the voluntary institution of waqf is needed nowadays, by setting up a non-government Muslim foundation which should provide public goods on large scale and attempt to combat illiteracy, sickness and lack of technical know-how. Khairunnisa Masuri, 2016 explained that collaboration of sukuk and waqf can be an innovation to have low cost fund to engine the economic sustainability of higher education institutions. So Waqf fund has great impact on distribution of wealth, redistribution of national income, increasing of employment and distributions of sources that will causes a stable economy. The higher education loan from takaful fund preconditioned to join as a member and repayment will be made to the fund once they have jobs and earning with a takaful contribution amount. The Takaful Alternative Student Finance (TASF) model is a unique student financing product has been initiated in UK to promote financial inclusion, particularly to avoid a subtle exclusion of those who are averse to interest-bearing student loans due to their religious beliefs. As per TASF model students are given loan from the takaful fund and students are repayment it via tax system to takaful fund. The accumulated students repayments remain in the fund are used to provide finance to the future students. Wahyu Jatmiko, 2018 explained that Introducing an integrated waqf (Islamic trust) and takaful (mutual guarantee) fund into the market can potentially reduce the student loan problem and help achieving optimum benefits for the society.

\section{METHODOLOGY}

This is a conceptual review study adopted for re-examination and evaluation of the higher education financing based on Islamic Shariah - an unconventional approach of student loan from the course of the existing and prominent research works and literatures. To do so, we conducted general searching of research works and literatures in the name of Education Financing, Shariah Based Financing, Qard Al Hassan, Qard Bil Ujrah, Waqf, and Takaful in the online data base sources such as Google Scholars, Spingers link, Wiley, Science Direct, JSTOR, Emerald full text, Scopus, and EBSCO HOST etc. From this general searching, we found a good number of research papers, journal articles, conference and any other type of works, in which we have gone through to select which articles or research papers require including in the review of this paper. Subsequently reading and analyzing thoroughly the most appropriate articles, we have collected those were found as the best fit within objectives of the higher education financing based on Islamic Shariah. The review has examined on the basis of objectives, methods and findings accordingly of the all collected empirical studies. 


\section{Qard Al Hassan}

\section{DISCUSSION}

Qard Al Hassan means beautiful, kindly, and benevolent loan. It is, basically, a welfare aimed interest free loan, in which the creditor may get return only the principle amount depending on the economic conditions and moral obligation of the borrower to return it (Bhuiyan, Ismail, Nor, Ali, \& Solaiman, 2020; Iqbal \& Shafiq, 2015; Mohieldin, Iqbal, Rostom, \& Fu, 2011). The holly Quran narrated the importance of quard al hassan in different verses $(2: 245 ; 57: 11 \& 18 ; 64: 17)$ and almighty Allah assures manifold return of it. Moreover Allah promises to remit sins and give a place in heaven to any person who lends to him. In holly Quran, Allah says, "If you establish worship and pay the poor due, and believe in my messengers and support them, and lend unto Allah a kindly loan, surely I shall remit your sins, and surely I shall bring you into gardens underneath which rivers flow" (Al-Quran, 5:12).In a hadith, prophet Mohammad (PBUH) said the quard al Hassan has distinct benefits over sadaqah and zakat to uphold the human dignity. Ibn Majah narrated in Vol. 3, Book 15, Hadith 2,431 "On the night on which I was taken on the Night Journey (Isra), I saw written at the gate of Paradise": "Charity brings a tenfold reward and a loan brings an eighteen fold reward". I said: "O Jibril! Why is a loan better than charity?" He said: "Because the beggar asks when he has something, but the one who asks for loan does so only because he is in need". So, it is vivid that Muslims and Islamic institutions practicing quard al hassan values are very much recommended to provide loan aimed at helping others on the basis of wealth redistribution, basic needs, and socioeconomic justice (Ali, 1989; Muneer \& Khan, 2019; Pramanik et al., 2015).

The Qard al-Hassan loan can be highly supportive investment to the poor and vulnerable group to meet their immediate basic needs. Moreover, the Qard al-Hassan loan might be extended to poor and underprivileged students on the basis of their merits and potentiality to adapt them in mainstream productive and economic activities (Iqbal \& Shafiq, 2015). But the devoted Muslims around the world are facing substantial hardship regarding the current student loan systems as it is mostly interest (riba) based loans which is utterly impermissible in Islamic shariah. In this case, potential devoted Muslim students can take loans without interest from a Qard-al-Hassan- based Islamic financial institutions on the basis of their merit, skills and expertise to up skill, reskill, and upgrade the knowledge of the recipients (Muneer \& Khan, 2019; Pramanik et al., 2015). Therefore, Islamic financial institutions can develop a qard al hassan based viable student loan system for poor and devoted Muslim students. This quard al hasanah instrument certainly will help to integrate the devoted Muslims in the mainstream of the society and to develop human resources. Finally, Qardal-hassan may help as an effective financial tool to heighten financial and social inclusion in society. By extending finance to potential unskilled and underprivileged, Qard-al-hassan helps achieving economic and social justice that is ultimately envisioned by the Islamic economics.

\section{Qard Bil Ujrah}

The word ujrah means fees, financial charges for service utilization and wages. The ujrah model solely based on fee or reward which is given by an individual or institution or agency to another person for the effort, work and work performance or service performed (Bhuiyan, Ismail, Ali, \& Solaiman, 2020; Husaeni, 2018). Proper rewarding for the service given is legal and permissible in Islamic shariah as long as they do not involve any element of riba (interest). Allah said in SurahalQasas: "One of the women said, "O my father, hire him. Indeed, the best one you can hire is the strong and the trustworthy". He said, "Indeed, I wish to wed you one of these, my two daughters, on [the condition] that you serve me for eight years; but if you complete ten, it will be [as a favor] from you. And I do not wish to put you in difficulty. You will find me, if Allah wills, from among the righteous" (Quran, 28:26, 27). In a hadith Abu Huraira narrated The Prophet said, "Allah did not send any prophet but shepherded sheep." His companions asked him, "Did you do the same?" The 
Prophet replied, "Yes, I used to shepherd the sheep of the people of Mecca for some Qirats" (alBuhārī \& Hān, 1997). In another hadith from 'Abdullah bin' Umar narrated that the Messenger of Allah said: "Give the worker his wages before his sweat dries". In this underlying ujrah credit concept, the Islamic financial institutions can provide credit schemes to the potential devoted students based on specific fees. The student loans unlike conventional financial institutions with interest (riba), the student loans under ujrah structure creates a fixed charges, which means fixed fee along with principles will be given by the recipient. The practice of ujrah model can keep devoted and potential students away from interest (riba), a course in the society, and help them attain higher skills and knowledge to integrate in the mainstream of the society.

\section{Waqf (Islamic Trust Bank)}

The etymological meaning of the Arabic word waqf is immobilization, detention, or standstill. In the legal context, waqf means detention of a property so that its produce or income may always be available for religious, educational or charitable purposes. When a waqf is created, the property is tied up forever and thereafter becomes non-transferable. Basically, the proceeds of waqf are earmarked to charity and philanthropy. Examples of beneficiaries include the poor and the needy. Waqf khayri is typically used to finance mosques, shelters, schools, and universities for education. This is meant to help financially-challenged individuals and communities. Waqf plays an important role in bringing out the equality and human resources development since the early of Islamic civilization history (Yalawae, Tahir, UDM, \& Campus, 2003). Allah s.w.t. says in His Holy book in surah al-Baqarah verse 267 which means: "Oh believers spent the best things of what you had obtained and what we had given out to you from the earth". The Prophet, Muhammad s.a.w. said about the waqf which was narrated by Imam al Bukhari through the saying of Caliph Omar r. a., that sounded: Oh Prophet! I got wealth that I never got it before and I want to be closer to Allah through it. After that the Prophet answered: You tried to keep the origin wealth and make charity out of it (by giving it to the needy and the people who deserved it). Then Caliph Omar r. a. donated his land which he got from the battle of Khaibar, and the land cannot be sold, even to be bought as well as to inherit it. As the devoted muslim students are struggling the interest (riba) issue in the conventional educational loan system, the Islamic waqf can use the waqf fund for educational funding that could finance student's education in term of fees and cost of living. The waqf fund Investment in human capital is believed to be the best investment that promises exponential growth and moreover it could bring the relief of Higher Education Loan to the Muslim community (Aziz, Yusof, Johari, Ramli, \& Sabri, 2014; Yalawae et al., 2003).

\section{Takaful}

Takaful means solidarity based mutual guarantee or assurance arrangement. When a group of people facing similar risks or the danger of incurring unforeseen losses, to individually contribute a certain sum of money, which will be used to compensate any member of the group who incurs such losses (Othman, 2017). There is no direct legal text in the Holy Qur'an and/or the Sunnah on the permissibility or non-permissibility of Takaful, but there are many legal texts in the Qur'an and prophetic precedents (hadith) that encourage the spirit of takaful which is based on cooperation, shared responsibility, joint indemnity, common interest and solidarity. Allah the Almighty said: "And help ye one another in righteousness and piety but help ye not one another in sin and rancour, and fear Allah for Allah is strict in punishment" (Qur'an, Surah al-Maidah, 5:2). Furthermore, the Prophet (PBUH) also advised the Muslims to help one another to relieve hardships, as narrated by Salim (r.a.): "And he who relieved a Muslim from hardship Allah would relieve him from the hardships to which he would be put on the Day of Resurrection..." (Sahih Muslim, Kitab al-Birr wa al-silah wa al adab). In addition to the above injunctions, the legality of takaful could also be 
supported with analogies (qiyas) with several practices in Islamic law which is similar to it. The International Islamic Fiqh Academy (IIFA) defined takaful as follows "Cooperative insurance is the process in which a group of people, who face certain risk(s), agree that each of them contribute a specific amount, based on cooperation, to a non-profit fund that is to be used for compensating anyone of them for the harms he would encounter when the risk in question materializes, as per signed contracts and adopted regulatory legislations". And the Accounting and Auditing Organization for Islamic Financial Institutions (AAOIFI) defines takaful as "a process of agreement among a group of persons to handle the injuries resulting from specific risks to which all of them are vulnerable". Therefore, takaful, regardless of how it is interpreted in other languages, is a Shariah compliant mutual assurance contractual structure, where participants contribute their resources to mitigate against future risks based on agreed terms (COMCEC, 2019).

An Integrated Takaful, solidarity based mutual guarantee, into the student financing market can potentially reduce the interest based student loan problem for devoted Muslim students. Unlike the traditional student loan, this model will give an interest-free loan to eligible students. The students who obtain the finance from this fund must join as members of the cooperative. Repayment will be made to the fund once they have jobs and earning above the repayment threshold. Instead of interest, they will repay a takaful contribution to the fund as a charitable gift for the benefit of the subsequent members to complete their studies. Therefore, the members of the fund basically help each other to attend higher education on the basis of mutual structure. This Takaful model can help largely to the Muslim students by financing higher education without sacrificing their faith.

\section{CONCLUSION AND POLICY RECOMMENDATION}

Higher education financing is contributing towards vast opportunities for the potential and underprivileged students to obtain quality education and better job, and finally have better income and standard of living. The development of shariah based higher education financing schemes can be a very effective tool for higher education financing as because many Muslims are struggling with the student loan issue due to the prohibition of interest (riba). The modes of shariah based Islamic financing i.e. Qard al Hassan (benevolent loan), Qard bil ujrah (Fee or charges of services), Waqf (Islamic trust bank), and Takaful (cooperative or solidarity based mutual guarantee) are well evidenced by Quran, Hadith, Islamic Jurisprudence, and eminent Islamic scholars' opinion. In Islamic economic perspective, shariah based student financing offerings bring immense opportunities and prospects to unlock new potentials. Due to having higher interest rate and system fragility of conventional student financing, the shariah based student financing is the best alternative and apparently the best solution for potential and underprivileged students. Islamic financial institutions with strong shariah, regulatory, and legal framework and comprehensive Islamic finance infrastructure is required to steer the shariah based student financing industry into new heights.

\section{REFERENCES}

al-Buhārī, M. I.-I., \& Hāan, M. M. (1997). The translation of the meanings of Sahîh Al-Bukhâri: Arabic-English. 9. Ahâdith 6861 to 7563: Darussalam.

Ali, A. Y. (1989). The Holy Qur'an: Text, Translation and Commentary (Brentwood, Maryland, USA: Amana Corporation). Ali, Yunasril.(2002). Jalan Kearifan Sui: Tasawuf sebagai Terapi Derita Manusia Jakarta: Serambi Ilmu semesta.

Avery, C., \& Turner, S. (2012). Student Loans: Do College Students Borrow Too Much--Or Not Enough? Journal of Economic Perspectives, 26(1), 165-192. 
Aziz, M. R. A., Yusof, M. A., Johari, F., Ramli, A., \& Sabri, H. (2014). The relief of higher education loan through Islamic waqf bank. Asian Social Science, 10(22), 175-181.

Becker, G. S. (1975). Investment in human capital: effects on earnings Human Capital: A Theoretical and Empirical Analysis, with Special Reference to Education, Second Edition (pp. 13-44): NBER.

Bhuiyan, A. B., Ismail, A. G., Ali, M. J., \& Solaiman, M. (2020). ISLAMIC ECONOMICS METHODOLOGY PATTERNS OF REASONING AND THE STRUCTURE OF THEORIES. International Journal of Shari'ah and Corporate Governance Research, 3(2), $10-24$.

Bhuiyan, A. B., Ismail, A. G., Nor, M. Z. B., Ali, M. J., \& Solaiman, M. (2020). THE ISLAMIC ECONOMICS PHILOSOPHY AND APPLICATION REALITY IN THE EXISTING ISLAMIC ECONOMIC ACTIVITIES IN THE WORLD. International Journal of Shari'ah and Corporate Governance Research, 3(2), 25-39.

Blom, A., \& Canton, E. (2004). Can student loans improve accessibility to higher education and student performance? An impact study of the case of SOFES, Mexico: The World Bank.

Chaiwut, K., Rueangsirarak, W., \& Chaisricharoen, R. (2018). Criteria Redesign for Student Loan Consideration Using Factor Analysis and Data Clustering Approach. ECTI Transactions on Computer and Information Technology (ECTI-CIT), 12(2), 153-164.

Husaeni, U. A. (2018). LAW ON FEE (UJRAH) IN GRATUITOUS CONTRACT: STUDY ON NATIONAL SHARIA BOARD-INDONESIAN COUNCIL OF 'ULAMĀ FATWĀ. Journal of Shariah Law Research, 3(1), 125-138.

Iqbal, Z., \& Shafiq, B. (2015). Islamic finance and the role of Qard-al-Hassan (Benevolent Loans) in enhancing inclusion: a case study of AKHUWAT. ACRN Oxford Journal of Finance and Risk Perspectives, 4(4), 23-40.

Johnstone, D. B., \& Shroff-Mehta, P. (2003). Higher education finance and accessibility: an international comparative examination of tuition and financial assistance policies. Globalization and reform in higher education, 11.

Li, W. (2013). The economics of student loan borrowing and repayment. Business Review Q, 3, 110.

Mohieldin, M., Iqbal, Z., Rostom, A., \& Fu, X. (2011). The role of Islamic finance in enhancing financial inclusion in Organization of Islamic Cooperation (OIC) countries: The World Bank.

Mueller, R. E., \& Rockerbie, D. W. (2004). Issues in Education Demand: The Ontario Experience. Retrieved June, 15, 2008. 
Muneer, F., \& Khan, F. (2019). Qard-Al-Hassan As a Tool for Poverty Alleviation a Case of Fael Khair Waqf Program in Bangladesh. Journal of Islamic Monetary Economics and Finance, 5(4), 829-848.

Mussa, A. (2015). Sustainability of higher education students' loan scheme (HESLS) in Tanzania.

Natek, S., \& Lesjak, D. (2011). Integrated Higher Education Information systems-Professors's knowledge management tools. Issues Inf Syst, 12, 80-86.

Othman, M. H. (2017). Takaful: Realities and Challenges. Institutions and Economies, 187-190.

Pramanik, A., Mohammed, M., Haneef, M., Amin, F., Aliyu, A., Dabour, N., \& Bağc1, K. (2015). Integration of Waqf And Islamic Microfinance For Poverty Reduction: Case Studies of Malaysia, Indonesia and Bangladesh. The Statistical, Economic and Social Research and Training Centre for Islamic Countries (SESRIC) and International Islamic University Malaysia. International Islamic University Malaysia (IIUM).

Psacharopoulos, G. (1986). Financing Education in Developing Countries: An Exploration of Policy Options: ERIC.

Salmi, J. (2003). Student loans in an international perspective: The World Bank experience. LCSHD paper series, 44.

Simon, F., Małgorzata, K., \& Beatriz, P. (2007). Education and training policy no more failures ten steps to equity in education: Ten steps to equity in education: OECD Publishing.

Yalawae, A., Tahir, I. M., UDM, U., \& Campus, K. (2003). The Role of Islamic Institution in Achieving Equality and Human Development: Waqf or Endowment. Universiti Darul Iman Malaysia (UDM).

Ziderman, A. (2013). Increasing access to higher education through student loans. CESifo DICE Report, 11(2), 11-18.

\section{Copyrights}

Copyright for this article is retained by the author(s), with first publication rights granted to the journal. This is an open-access article distributed under the terms and conditions of the Creative Commons Attribution license (http://creativecommons.org/licenses/by/4.0) 